Article

\title{
Analysis of Migration of Polycyclic Aromatic Hydrocarbons from Sewage Sludge Used for Fertilization to Soils, Surface Waters, and Plants
}

\author{
Ewa Stańczyk-Mazanek*(D), Longina Stępniak and Urszula Kępa ${ }^{\mathbb{D}}$ \\ The Faculty of Infrastructure and Environment, Czestochowa University of Technology, 42-201 Czestochowa, \\ Poland; stepniak@is.pcz.czest.pl (L.S.); kepa@is.pcz.czest.pl (U.K.) \\ * Correspondence: stanczyk@is.pcz.czest.pl; Tel.: +48-505-015-775
}

Received: 4 April 2019; Accepted: 9 June 2019; Published: 18 June 2019

check for updates

\begin{abstract}
In this paper, we discuss the effect sewage sludge (SS) application has on the contamination of polycyclic aromatic hydrocarbons in fertilized soils and groundwater. Morver, the contents of these compounds in plant biomass was analyzed. For six months, composted sewage sludge was introduced into sandy soil. The research was conducted under lysimetric experiment conditions with the possibility of collecting soil leachate in natural conditions. The following doses of sewage sludge were used: $0,10,20,30$, and $40 \mathrm{t} /$ ha calculated per experimental object containing $10 \mathrm{~kg}$ of sandy soil. The examinations were carried out within a three-year time frame. Dactylis glomerata grass was grown on the fertilized soils. Every year, the content of polycyclic aromatic hydrocarbons (PAHs) was collected from fertilized objects and analyzed in soil leachate, which can contaminate surface water. The following six polycylic aromatic hydrocarbons defined by Polish standards were determined: benzo(b)fluoranthene, benzo(k)fluoranthene, benzo(a)pyrene, dibenz(a,h)anthracene, and benzo(g,h,i)perylene, indeno(1,2,3-cd)pyrene. Further, the content of PAHs in soils and the bioaccumulation of these compounds in cultivated plants were evaluated after each year. The results of the study showed that the increase in the dose of sewage sludge used for soil fertilization led to the rise in the amount of polycyclic aromatic hydrocarbons analyzed in the soil. The compounds migrated to cultivated plants. This phenomenon was observed especially in the first year following soil fertilization with sewage sludge. Excessive accumulation of PAHs (especially benzo(a)pyrene) was observed in plant biomass in the first year of a lysimetric experiment after sewage sludge fertilization with doses greater than $10 \mathrm{t} / \mathrm{ha}$. The increase in bioaccumulation of this compound in plant biomass compared to control objects was $138 \%, 288 \%$, and 505\% after application of 20, 30, and 40 t/ha, respectively. Fertilization with sewage sludge did not cause contamination with PAHs in water leachates from the soils.
\end{abstract}

Keywords: fertilization; sewage sludge; polycyclic aromatic hydrocarbons (PAHs); groundwater; soil; biomass

\section{Introduction}

One sewage sludge (SS) disposal method based on fertilization capacity of sludge is its application in agriculture and forestry. The precondition for such use is permissible contents of heavy metals and sanitary contamination that meet the recommendations. The danger associated with the use of these wastes as fertilizer materials is related to their frequent chemical and biological pollution [1-3]. Sludge used for soil fertilization might cause migration of polycyclic aromatic hydrocarbons, which cause contamination of soil, groundwater, and plant biomass. Numerous scientific reports have indicated sewage sludge as a source of PAHs in the soil environment [4-7].

Polycyclic aromatic hydrocarbons are numbered among so-called persistent organic pollutants. They are characterized by high toxicity, very high durability, and the ability to accumulate 
in the soil environment. Among PAHs, strong carcinogenic and mutagenic properties are observed in benzo(a)pyrene, benzo(b)fluoranthene, benzo(k)fluoranthene, indeno(1,2,3-cd)pyrene, dibenzo(a,h)anthracene, and benzo(g,h,i)perylene. The greatest threat to the environment, including soil and surface waters, are compounds with high molecular mass, with five or more aromatic rings. This is due to their much slower degradation in the environment and accumulation in soils and sludge $[8,9]$. According to the literature, about $95 \%$ of polycyclic aromatic hydrocarbons are removed [10] during wastewater treatment processes. The content of polycyclic aromatic hydrocarbons is considerably reduced during thermal processing at higher temperatures and during the composting process [9]. Some authors have emphasized that an increase in temperature during composting will limit the development of microorganisms that degrade PAHs to less hazardous forms. This was demonstrated in studies that analyzed the effect of the fungus Trametes versicolor on the processes of treatment of aromatic hydrocarbons during composting conditions [11]. Other authors [12] demonstrated the important role of Luteimonas, Glutamicibacter, Alcanivorax, Dechloromonas, Ferribacterium, Truepera, and Sphingobacterium in the degradation of PAHs in sewage sludge from industrial wastewater during composting.

However, some authors have reported that anaerobic degradation of sewage sludge does not cause considerable changes in polycyclic aromatic hydrocarbons levels [13]. Furthermore, some studies found an increase in the content of these organic compounds after the fermentation process [14]. This phenomenon has been explained as a possible biotransformation of organic compounds by active microorganisms in the processes of sewage sludge processing. Similarly differentiated results were obtained by Boruszko [15], who documented both a decrease and an increase in the contents of PAHs in dairy sewage sludge following fermentation. Boruszko emphasized an important role of microorganism activity in the transformation and decomposition of polycyclic aromatic hydrocarbons. Further, his research demonstrated the substantial effect of EMs (effective microorganisms). Other authors have also emphasized the positive effect of microorganisms in the treatment of PAHs in the environment [7].

The use of sewage sludge for agricultural purposes, including soil fertilization, may contribute to the contamination of groundwater in fertilized areas. Opinions on the mobility of polycyclic aromatic hydrocarbons in the soil environment are divided. However, polycyclic aromatic hydrocarbons are mostly considered to be quite mobile in the environment, especially in soils with a low content of organic matter, which can accumulate and temporarily immobilize these compounds. Therefore, there is a real risk of contamination of soils, subsurface waters, and even cultivated plant biomass. One of the methods limiting the risk of polycyclic aromatic hydrocarbons migration in soil after the use of sewage sludge in agriculture may be the application of biochar with sludge $[16,17]$. Past studies have demonstrated that this fertilization method reduces mobility of polycyclic hydrocarbons in the soil and facilitates gradual decomposition. The greatest properties limiting the toxicity of PAHs from sewage sludge used in the soil environment were found for biochar produced at $600{ }^{\circ} \mathrm{C}$.

In Poland, polycyclic aromatic hydrocarbons content is not a legal limit used for choosing a method of sewage sludge disposal. However, the European Commission has proposed to amend Directive 1986/278/EEC to include a permissible value for the total of 11 PAHs, including acenaphthene, phenanthrene, fluorene, fluoranthene, pyrene, benzo(b)fluoranthene, benzo(j)fluoranthene, benzo(k) fluoranthene, benzo(a)pyrene, and benzo(g,h,i)perylene, indeno(1,2,3-cd)pyrene in $6 \mathrm{mg} / \mathrm{kg}$ of sludge [18].

The main aim of the research was to analyze the migration of polycyclic aromatic hydrocarbons from sewage sludge to the soil fertilized with the sludge. Migration of PAHs to groundwater and bioaccumulation in the biomass of cultivated plants (Dactylis glomerata) were also examined.

\section{Materials and Methods}

Over a three-year period (May 2015 to September 2017), we researched the migration of polycyclic aromatic hydrocarbons from sewage sludge to the fertilized soil, followed by the migration of leachates to groundwater. This research was conducted using the lysimetric experiment in a foil tunnel. Loamy soil was used in the experiment and oncentration of heavy metals in the soils was determined according to the recommendations [19]. Table 1 presents the below permissible levels of these elements in soils 
qualified for fertilization with sewage sludge. The contents of heavy metals in sewage sludge made it possible to use the sludge for agricultural purposes [20].

In the lysimetric experiment, we used sewage sludge from medium-size wastewater treatment plant for fertilization purposes. The sludge was obtained from biological sewage treatment using the activated sludge method, followed by aerobic stabilization.

The experiment was conducted in polyethylene lysimeters with a capacity of $10 \mathrm{~kg}$ adapted to leachate sampling. The lysimeters were filled with sandy soil (marked "S" in the tables) and fertilized with sewage sludge (SS). The objects were fertilized with doses calculated per lysimeter so that they corresponded to the contents of 10, 20, 30, and $40 \mathrm{t} / \mathrm{ha}$. Moreover, the experimental design included control objects with non-fertilized soil (marked "C" in the tables). The soils prepared as above were sown with Dactylis glomerata grass. This species was chosen for research since the plant is fast-growing and produces an extensive root system. Its clumps grow strongly and outcompete other species, and it is insensitive to drought and cold. Furthermore, the species ensures a high biomass yield. It is also often used for plant toxicological studies to assess soil quality, as it accumulates various types of contaminants.

The lysimetric experiment did not use mineral fertilization. The humidity in all objects was maintained at a $60 \%$ level of maximum water capacity via watering. Leachate collected from research objects was analyzed once a year after the end of the growing season for leaching polycyclic aromatic hydrocarbons from soil mixtures. The analyses were repeated in the second and third years of the experiments.

Soil and sewage sludge samples were initially dried at room temperature and sieved through a sieve with a $2 \mathrm{~mm}$ mesh. They were then dried at $105^{\circ} \mathrm{C}$ to a constant mass and ground in a mortar. Next, they were sieved again through a sieve with a mesh diameter of $1.0 \mathrm{~mm}$. Three samples were prepared for analysis. The following determinations were made: organic substance, $\mathrm{pH}$ in $\mathrm{H}_{2} \mathrm{O}$, organic carbon, total nitrogen, available $\mathrm{P}, \mathrm{K}$, and $\mathrm{M}$, according to the methodology recommended in Poland [19-21].

The total contents of heavy metals in soil and SS were also determined: copper, lead, cadmium, zinc, nickel, chromium, and mercury. Aqua regia (a mixture of concentrated hydrochloric and nitric acids at a volumetric ratio of 3:1) was used to extract the metals. Mineralization was conducted at $180{ }^{\circ} \mathrm{C}$ for $30 \mathrm{~min}$, using a high-pressure microwave mineralizer MWS-2 (BERGHOF Products and Intruments $\mathrm{GmbH}$, Eningen, Germany). The contents of heavy metals were evaluated using an optical emission specrometer with a plasma excitation SPECTRO ARCOS FHX22 (SPECTRO Analytical Instruments GmbH, Kleve, Germany).

After the end of each year, we studied the polycyclic aromatic hydrocarbons content in soils (taken from lysimeters from a depth of $25 \mathrm{~cm}$ ) and in plant biomass.

Air-dry samples of sewage sludge, soil, and plant biomass (dried at $20^{\circ} \mathrm{C}$ ) were milled and pre-sieved through a sieve with $1 \mathrm{~mm}$ mesh. The preliminary stage before chromatographic determination of PAHs in sewage sludge, soil, and plant biomass was to extract it with organic solvents of various polarity. Separation of the organic matrix was performed by means of sonolysis using a mixture of solvents: cyclohexane and dichloromethane $(5: 1 \mathrm{v} / \mathrm{v})$. Separation of solvent extracts from the sample was conducted using a high-speed centrifuge MPW M-SCIENCE (MPW MED. INSTRUMENTS, Warszawa, Poland). A silica gel was used to isolate analytes from extracts from simultaneously extracted organic substances. The treatments were conducted under vacuum conditions. Purified extracts were concentrated in a nitrogen stream. The determinations were performed using a gas chromatograph coupled with a mass spectrometer-model GC800/MS800 (Fisons, Ringoes, NJ, USA). In the research, 16 polycyclic aromatic hydrocarbons indicated in the Environmental Protection Agency (EPA) list were determined for environmental analyses. These included: naphthalene, acenaphthylene, acenaphthene, fluorene, phenanthrene, anthracene, fluoranthene, pyrene, benzo(a)anthracene, chrysene, benzo(b)fluoranthene, benzo(k)fluoranthene, benzo(a)pyrene, dibenzo(ah)anthracene, and benzo(ghi)perylene and indeno(123cd)pyrene.

In sewage sludge, we calculated a 11 polycyclic aromatic hydrocarbons [18] to evaluate their properties and usefulness for fertilization. In the soils fertilized with SS, 10 PAHs [21] were analyzed. Lastly, six PAHs were determined from the leachates in lysimeters [22]. The correlation coefficient 
between the six PAHs in the soil leachates and the compounds in plant biomass (D. glomerata) were calculated based on the research results. Further, the correlation coefficients between the migration of the six analyzed PAHs, the leachate from soil, and the duration of the research were calculated. The correlation between the dose of sewage sludge and migration of PAHs from leachates to plant biomass was also analyzed. All tests were carried out with three repetitions. The results are represented by arithmetic mean.

\section{Results and Discussion}

The physical and chemical characteristics of the materials used in the examinations are presented in Tables 1 and 2. Tables 3-5 present the results of the PAH contents in soil mixtures fertilized with sewage sludge, leachate from these soils, and plant biomass from $D$. glomerata.

Table 1. Physical and chemical properties of soil and sewage sludge used in the lysimeter experiment.

\begin{tabular}{cccc}
\hline Parameter & Unit & S & SS \\
\hline Organic substance & {$[\%$ d.m.] } & 0.8 & 47.0 \\
\hline Reaction $\left(\mathrm{pH}_{\mathrm{H} 20}\right)$ & - & 6.4 & 8.2 \\
\hline $\mathrm{H}_{\mathrm{h}}$ (hydrolytic acidity) & {$[\mathrm{me} / 100 \mathrm{~g}]$} & 2.6 & - \\
\hline Organic carbon & \multirow{2}{*}[\mathrm{gg}^{-1}\mathrm{d}.\mathrm{m}.]{} & 9.65 & 230 \\
Total nitrogen & & 0.65 & 37.12 \\
\hline Available $\mathrm{P}$ & & 35.12 & 611.5 \\
Available $\mathrm{K}$ & & 19.49 & 262.4 \\
Available $\mathrm{Mg}$ & 59.9 & 885.4 \\
$\mathrm{Cr}$ & 1.6 & 19 \\
$\mathrm{Zn}$ & 3.6 & 775 \\
$\mathrm{~Pb}$ & & 7.1 & 27 \\
$\mathrm{Cu}$ & & 1.1 & 156 \\
$\mathrm{Cd}$ & & 0.1 & 2.6 \\
$\mathrm{Ni}$ & & 0.92 & 120.1 \\
$\mathrm{Hg}$ & & 0.0018 & 0.52 \\
\hline
\end{tabular}

S: soil; SS: sewage sludge; d.m.: dry mass.

Table 2. Contents of polycyclic aromatic hydrocarbons (PAH) in soil and sewage sludge used in the lysimeter experiment.

\begin{tabular}{|c|c|c|c|}
\hline Type of PAH & Unit & $S$ & SS \\
\hline Naphthalene & & $2.8 \pm 0.22$ & $1040 \pm 10.2$ \\
\hline Acenaphthylene & & $4 \pm 0.50$ & $86 \pm 6.14$ \\
\hline Acenaphthalene * & & $0.2 \pm 0.06$ & $100 \pm 6.2$ \\
\hline Flouorene* & & $0.3 \pm 0.05$ & $22 \pm 2.14$ \\
\hline Phenanthrene* & & $1.4 \pm 0.15$ & $672 \pm 6.12$ \\
\hline Anthracene & & $0.2 \pm 0.04$ & $114 \pm 5.24$ \\
\hline Fluoranthene * & & $0.9 \pm 0.24$ & $1080 \pm 16.4$ \\
\hline Pyrene * & & $0.8 \pm 0.25$ & $759 \pm 15.3$ \\
\hline Benzo(a)anthracene & {$\left[\mu \mathrm{g} \cdot \mathrm{kg}^{-1} \mathrm{~d} \cdot \mathrm{m}\right]$} & $0.2 \pm 0.05$ & $607 \pm 7.1$ \\
\hline Chrysene & & $0.4 \pm 0.02$ & $1270 \pm 17.3$ \\
\hline Benzo(b)fluoranthene * & & $0.4 \pm 0.03$ & $1070 \pm 11.3$ \\
\hline Benzo(k)fluoranthene * & & $0.2 \pm 0.03$ & $470 \pm 9.33$ \\
\hline Benzo(a)pyrene * & & $0.3 \pm 0.04$ & $718 \pm 15.6$ \\
\hline Dibenzo(a,h)anthracene & & $0.2 \pm 0.02$ & $219 \pm 4.11$ \\
\hline Benzo(g,h,i)perylene * & & $0.7 \pm 0.07$ & $660 \pm 8.2$ \\
\hline Indeno $(1,2,3-\mathrm{cd})$ pyrene * & & $0.2 \pm 0,04$ & $820 \pm 9.7$ \\
\hline $\begin{array}{l}\text { Total of } 16 \text { PAHs } \\
\text { [according to US EPA] }\end{array}$ & & 13.0 & 9212 \\
\hline $\begin{array}{l}\text { Total of } 11 \text { PAHs }\left(^{*}\right) \\
\text { [according to the EU's directive] }\end{array}$ & & 5.6 & 6866 \\
\hline
\end{tabular}

*: Determination of PAHs adopted in the European Union (EU) recommendations in sewage sludge intended for fertilization purposes. 
Table 3. Content of PAH in soil mixtures [ $\mu \mathrm{g} / \mathrm{kg}$ d.m.].

\begin{tabular}{|c|c|c|c|c|c|c|c|c|c|c|c|c|c|c|c|}
\hline \multirow{3}{*}{$\begin{array}{c}\text { Contents of Polycyclic } \\
\text { Aromatic Hydrocarbons } \\
\text { [ug.kg-1 d.m.] }\end{array}$} & \multicolumn{5}{|c|}{ One Year of Experience } & \multirow{2}{*}{\multicolumn{5}{|c|}{$\begin{array}{c}\text { Two Years of Experience } \\
\text { Type of Fertilizer Combination }\end{array}$}} & \multicolumn{5}{|c|}{ Three Years of Experience } \\
\hline & & & & & & & & & & & & & & & \\
\hline & C & S+SS 10 & S+SS 20 & $\mathrm{~S}+\mathrm{SS} 30$ & S+SS 40 & C & S+SS 10 & S+SS 20 & S+SS 30 & S+SS 40 & C & S+SS 10 & S+SS 20 & S+SS 30 & $\mathrm{~S}+\mathrm{SS} 40$ \\
\hline Naphthalene & $2.30 \pm 0.22$ & $4.30 \pm 0.20$ & $5.00 \pm 0.55$ & $6.00 \pm 0.60$ & $5.30 \pm 0.53$ & $2.17 \pm 0.21$ & $4.10 \pm 0.22$ & $4.40 \pm 0.22$ & $5.20 \pm 0.56$ & $5.00 \pm 0.35$ & $2.10 \pm 0.22$ & $3.90 \pm 0.21$ & $4.00 \pm 0.23$ & $3.90 \pm 0.13$ & $4.80 \pm 0.26$ \\
\hline Anthracene & $0.13 \pm 0.01$ & $0.27 \pm 0.03$ & $0.60 \pm 0.03$ & $0.70 \pm 0.08$ & $0.74 \pm 0.02$ & $0.10 \pm 0.01$ & $0.17 \pm 0.03$ & $0.31 \pm 0.02$ & $0.35 \pm 0.02$ & $0.40 \pm 0.08$ & n.d. & n.d. & n.d. & $0.10 \pm 0.02$ & $0.14 \pm 0.02$ \\
\hline Chrysene & $0.27 \pm 0.04$ & $1.10 \pm 0.03$ & $3.20 \pm 0.23$ & $5.10 \pm 0.53$ & $5.47 \pm 0.51$ & $0.93 \pm 0.06$ & $0.90 \pm 0.03$ & $1.50 \pm 0.06$ & $2.80 \pm 0.23$ & $3.50 \pm 0.21$ & $0.70 \pm 0.03$ & $0.70 \pm 0.05$ & $1.60 \pm 0.06$ & $2.10 \pm 0.23$ & $2.67 \pm 0.22$ \\
\hline Benzo(a)antracene & $0.13 \pm 0.03$ & $1.10 \pm 0.02$ & $2.70 \pm 0.21$ & $3.90 \pm 0.13$ & $4.03 \pm 0.23$ & $0.20 \pm 0.04$ & $0.90 \pm 0.06$ & $1.20 \pm 0.22$ & $1.10 \pm 0.23$ & $1.90 \pm 0.20$ & $0.17 \pm 0.03$ & $0.70 \pm 0.08$ & $1.00 \pm 0.03$ & $1.50 \pm 0.22$ & $1.57 \pm 0.20$ \\
\hline Dibenzo(a,h)anthracene & $0.20 \pm 0.03$ & $0.20 \pm 0.02$ & $0.23 \pm 0.03$ & $0.30 \pm 0.07$ & $0.30 \pm 0.05$ & n.d & n.d. & n.d. & n.d. & n.d. & n.d. & n.d. & n.d. & n.d. & n.d. \\
\hline Benzo(a)pyrene & $0.30 \pm 0.06$ & $0.70 \pm 0.05$ & $1.80 \pm 0.20$ & $3.10 \pm 0.21$ & $3.07 \pm 0.17$ & $0.20 \pm 0.02$ & $0.53 \pm 0.08$ & $1.30 \pm 0.13$ & $1.20 \pm 0.23$ & $1.87 \pm 0.093$ & $0.10 \pm 0.06$ & $0.40 \pm 0.08$ & $1.10 \pm 0.0 .2$ & $1.00 \pm 0.13$ & $1.50 \pm 0.06$ \\
\hline Benzo(b)fluoranthene & $0.33 \pm 0.07$ & $0.90 \pm 0.06$ & $2.60 \pm 0.03$ & $4.50 \pm 0.23$ & $4.97 \pm 0.27$ & $0.37 \pm 0.07$ & $0.77 \pm 0.03$ & $2.10 \pm 0.23$ & $2.90 \pm 0.23$ & $4.70 \pm 0.26$ & $0.30 \pm 0.07$ & $0.63 \pm 0.03$ & $1.50 \pm 0.13$ & $2.10 \pm 0.23$ & $3.40 \pm 0.33$ \\
\hline Bbenzo(k)fluoranthene & $0.10 \pm 0.03$ & $0.40 \pm 0.07$ & $1.10 \pm 0.06$ & $1.30 \pm 0.23$ & $1.23 \pm 0.15$ & $0.10 \pm 0.01$ & $0.30 \pm 0.02$ & $0.47 \pm 0.05$ & $0.80 \pm 0.03$ & $0.87 \pm 0.05$ & $0.09 \pm 0.01$ & $0.30 \pm 0.02$ & $0.45 \pm 0.07$ & $0.50 \pm 0.05$ & $0.63 \pm 0.07$ \\
\hline Benzo(g,h,i)perylene & n.d. & $0.09 \pm 0.02$ & $0.09 \pm 0.01$ & $1.00 \pm 0.03$ & $1.10 \pm 0.01$ & n.d. & n.d. & n.d. & n.d. & $0.09 \pm 0.01$ & n.d. & n.d. & n.d. & n.d. & n.d. \\
\hline Indeno(1,2,3-cd)pyrene & n.d. & n.d. & $0.09 \pm 0.01$ & $0.90 \pm 0.03$ & $1.00 \pm 0.13$ & n.d. & n.d. & n.d. & n.d. & $0.09 \pm 0.01$ & n.d. & n.d. & n.d. & n.d. & n.d. \\
\hline 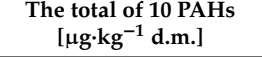 & 3.76 & 9.06 & 17.41 & 26.8 & 27.21 & 4.07 & 7.67 & 11.28 & 14.35 & 18.42 & 3.46 & 6.63 & 9.65 & 11.20 & 14.71 \\
\hline
\end{tabular}

n.d: not detected; \pm : standard deviation; d.m.: dry mass.

Table 4. Content of PAH in leachate from soil mixtures [ng/L].

\begin{tabular}{|c|c|c|c|c|c|c|c|c|c|c|c|c|c|c|c|}
\hline \multirow{3}{*}{$\begin{array}{c}\text { Contents of Polycyclic } \\
\text { Aromatic Hydrocarbons [ng/L] }\end{array}$} & \multicolumn{5}{|c|}{ One Year of Experience } & \multicolumn{5}{|c|}{ Two Years of Experience } & \multicolumn{5}{|c|}{ Three Years of Experience } \\
\hline & \multicolumn{15}{|c|}{ Type of Fertilizer Combination } \\
\hline & C & S+SS 10 & S+SS 20 & S+SS 30 & S+SS 40 & C & S+SS 10 & S+SS 20 & S+SS 30 & S+SS 40 & C & S+SS 10 & S+SS 20 & S+SS 30 & S+SS 40 \\
\hline Benzo(b)fluoranthene & $6.10 \pm 0.65$ & $9.20 \pm 0.83$ & $13.10 \pm 0.13$ & $18.62 \pm 1.51$ & $24.40 \pm 2.13$ & $2.50 \pm 0.20$ & $4.60 \pm 0.21$ & $6.33 \pm 0.77$ & $8.13 \pm 0.56$ & $9.90 \pm 0.63$ & $1.30 \pm 0.20$ & $1.40 \pm 0.25$ & $4.12 \pm 0.31$ & $4.82 \pm 0.42$ & $5.10 \pm 0.43$ \\
\hline Benzo(k)fluoranthene & $4.80 \pm 0.32$ & $5.20 \pm 0.63$ & $6.17 \pm 0.70$ & $6.94 \pm 0.65$ & $8.70 \pm 0.31$ & $2.60 \pm 0.37$ & $4.80 \pm 0.33$ & $4.10 \pm 0.77$ & $3.90 \pm 0.21$ & $4.95 \pm 0.43$ & $1.50 \pm 0.20$ & $1.50 \pm 0.06$ & $2.10 \pm 0.23$ & $2.50 \pm 0.21$ & $3.60 \pm 0.31$ \\
\hline Benzo(a)pyrene & $4.10 \pm 0.25$ & $5.24 \pm 0.38$ & $9.60 \pm 0.52$ & $15.80 \pm 0.71$ & $18.10 \pm 0.92$ & $2.16 \pm 0.23$ & $2.60 \pm 0.37$ & $5.14 \pm 0.42$ & $7.28 \pm 0.64$ & $8.13 \pm 0.97$ & $0.90 \pm 0.07$ & $1.00 \pm 0.10$ & $1.90 \pm 0.23$ & $3.42 \pm 0.21$ & $5.10 \pm 0.37$ \\
\hline Dibenzo $(a, h)$ anthracene & $6.30 \pm 0.27$ & $6.80 \pm 0.42$ & $6.95 \pm 0.51$ & $7.13 \pm 0.67$ & $7.10 \pm 0.93$ & n.d. & n.d. & n.d. & n.d. & n.d. & n.d. & n.d. & n.d. & n.d. & n.d. \\
\hline Benzo(g,h,i)perylene & $9.25 \pm 0.46$ & $9.40 \pm 0.52$ & $14.90 \pm 0.13$ & $16.40 \pm 0.22$ & $20.10 \pm 1.20$ & $7.10 \pm 0.62$ & $6.90 \pm 0.52$ & $8.12 \pm 0.98$ & $9.13 \pm 0.97$ & $9.52 \pm 0.31$ & $1.20 \pm 0.27$ & $2.11 \pm 024$ & $3.40 \pm 0.33$ & $5.00 \pm 0.57$ & $8.70 \pm 0.43$ \\
\hline Indeno(1,2,3-cd)pyrene & $6.10 \pm 0.42$ & $8.73 \pm 0.50$ & $10.45 \pm 0.12$ & $12.60 \pm 0.73$ & $16.80 \pm 1.30$ & $2.60 \pm 0.42$ & $4.90 \pm 0.32$ & $4.17 \pm 0.23$ & $8.00 \pm 0.31$ & $8.73 \pm 0.47$ & $1.13 \pm 0.21$ & $2.60 \pm 0.29$ & $3.23 \pm 0.37$ & $5.10 \pm 0.52$ & $6.10 \pm 0.57$ \\
\hline The total of 6 PAHs & 36.65 & 44.57 & 61.17 & 77.49 & 95.20 & 16.96 & 23.80 & 27.86 & 36.44 & 41.23 & 6.03 & 8.61 & 14.75 & 20.84 & 28.60 \\
\hline
\end{tabular}

n.d: not detected; \pm : standard deviation. 
Table 5. Content of PAH in biomass from D. glomerata from soil mixtures with sewage sludge [ $\mu \mathrm{g} / \mathrm{kg}$ d.m.].

\begin{tabular}{|c|c|c|c|c|c|c|c|c|c|c|c|c|c|c|c|}
\hline \multirow{3}{*}{$\begin{array}{l}\text { Contents of Polycyclic } \\
\text { Aromatic Hydrocarbons } \\
{\left[\mu \mathrm{kg} \cdot \mathrm{kg}^{-1} \text { d.m.] }\right.}\end{array}$} & \multicolumn{5}{|c|}{ One Year of Experience } & \multicolumn{5}{|c|}{ Two Years of Experience } & \multicolumn{5}{|c|}{ Three Years of Experience } \\
\hline & \multicolumn{15}{|c|}{ Type of Fertilizer Combination } \\
\hline & C & S+SS 10 & S+SS 20 & $\mathrm{~S}+\mathrm{SS} 30$ & S+SS 40 & $\mathrm{C}$ & S+SS 10 & S+SS 20 & S+SS 30 & S+SS 40 & $\mathrm{C}$ & S+SS 10 & S+SS 20 & S+SS 30 & S+SS 40 \\
\hline Naphthalene & 3.21 & 9.90 & 24.10 & 167.20 & 280.30 & 1.13 & 1.10 & 1.30 & 4.21 & 10.10 & n.d. & n.d. & n.d. & 1.20 & 3.34 \\
\hline Acenaphthalene & 14.95 & 14.20 & 19.20 & 27.30 & 35.05 & 1.06 & 1.10 & 1.50 & 2.00 & 2.55 & n.d. & n.d. & n.d. & n.d & 0.50 \\
\hline Acenaphthene & 1.70 & 6.60 & 7.80 & 11.60 & 12.00 & n.d. & 1.10 & 1.20 & 1.10 & 1.30 & n.d. & n.d. & n.d. & n.d. & n.d. \\
\hline Fluorene & 4.60 & 7.70 & 8.00 & 12.30 & 11.70 & n.d. & 1.2 & n.d & n.d. & 2.10 & n.d. & n.d. & n.d. & n.d. & n.d. \\
\hline Phenanthrene & 23.50 & 21.80 & 67.90 & 115.60 & 128.50 & 1.07 & 1.13 & 2.70 & 4.50 & 3.00 & n.d. & n.d. & n.d. & n.d. & 0.50 \\
\hline Anthracene & 1.10 & 2.37 & 3.10 & 4.20 & 4.54 & n.d. & n.d. & n.d. & n.d. & n.d. & n.d. & n.d. & n.d. & n.d. & n.d. \\
\hline Fluoranthene & 5.77 & 4.20 & 9.00 & 16.40 & 22.64 & n.d. & n.d. & 1.00 & 4.20 & 3.00 & n.d. & n.d. & n.d. & n.d. & n.d. \\
\hline Pyrene & 4.10 & 4.20 & 15.50 & 38.80 & 47.80 & n.d. & n.d. & 1.10 & 1.80 & 2.50 & n.d. & n.d. & n.d. & n.d. & n.d. \\
\hline Chrysene & 1.27 & 1.33 & 4.20 & 7.80 & 8.17 & n.d. & n.d. & n.d. & n.d. & 1.10 & n.d. & n.d. & n.d. & n.d. & n.d. \\
\hline Benzo(a)antracene & 0.90 & 0.97 & 1.00 & 1.42 & 1.67 & n.d. & n.d. & n.d. & n.d. & 0.70 & n.d. & n.d. & n.d. & n.d. & n.d. \\
\hline Dibenz(a,h)anthracene & 0.87 & 0.83 & 0.96 & 1.55 & 1.63 & n.d. & n.d. & n.d. & 0.60 & 0.72 & n.d. & n.d. & n.d. & n.d. & n.d. \\
\hline Benzo(a)pyrene & 0.80 & 0.74 & 1.90 & 3.10 & 4.84 & n.d. & n.d. & n.d. & n.d. & n.d. & n.d. & n.d. & n.d. & n.d. & n.d. \\
\hline Benzo(b)fluoranthene & 0.87 & 0.80 & 1.90 & 4.90 & 7.77 & n.d. & n.d. & n.d. & n.d. & 0.50 & n.d. & n.d. & n.d. & n.d. & n.d. \\
\hline Benzo(k)fluoranthene & 0.74 & 0.70 & 1.90 & 2.60 & 3.43 & n.d. & n.d. & n.d. & n.d. & n.d. & n.d. & n.d. & n.d. & n.d. & n.d. \\
\hline Benzo(g,h,i)perylene & 0.80 & 2.20 & 3.00 & 3.10 & 4.87 & n.d. & n.d. & n.d. & n.d. & n.d. & n.d. & n.d. & n.d. & n.d. & n.d. \\
\hline Indeno( $(1,2,3-\mathrm{cd})$ pyrene & 0.80 & 0.77 & 0.90 & 2.10 & 3.24 & n.d. & n.d. & n.d. & n.d. & n.d. & n.d. & n.d. & n.d. & n.d. & n.d. \\
\hline $\begin{array}{l}\text { The total of } 16 \text { PAHs } \\
{\left[\mu \mathrm{ug}^{-\mathrm{kg}^{-1}} \text { d.m.] }\right.}\end{array}$ & 65.98 & 79.31 & 170.36 & 419.97 & 578.15 & 3.26 & 5.63 & 8.80 & 18.41 & 27.57 & n.d. & n.d. & n.d. & 1.20 & 4.34 \\
\hline
\end{tabular}

n.d: not detected; \pm ; d.m.: dry mass. 
The $\mathrm{pH}$ (Table 1) value in the soil used in the lysimetric experiment was 6.4 and according to the fertilization recommendations [16] exhibited a poor acid reaction. According to the Institute of Soil Science and Plant Cultivation (IUNG) guidelines used to evaluate the degree of contamination of soils with heavy metals in the sandy soil used for fertilization in the lysimeter experiment, the contents of other standard metals such as zinc, lead, copper, cadmium, and nickel can be defined as natural content (0 degree of soil contamination) [21,23]. Concentration of heavy metals in the soils were below permissible levels recommended for fertilization with sewage sludge [20].

The amount of organic matter in the soil used for fertilization was $0.8 \%$ dry mass (d.m.). Fertile soils with a large amount of organic matter are those containing 3\% d.m. On average, in soils for cultivation in Poland, the amount of this component ranges between 1 and $5 \%$. The amount of organic carbon in the studied soil was $9.65 \mathrm{~g} \cdot \mathrm{kg}^{-1} \mathrm{~d} . \mathrm{m}$., indicating a low humus content. The determined amounts of other soil components, including biogenic compounds (e.g., N, P, K, Mg) also indicated low soil abundance [19]. Hydrolytic acidity $\left(\mathrm{H}_{\mathrm{h}}\right)$ in sandy soil used subsequently for sewage sludge fertilization was 2.6 [me/100 g]. This parameter indicated a high degree of potential acidity. In light arable soils (with a small capacity of a sorption complex), hydrolytic acidity values usually range from 1 to 3 milliequivalents (me) per $100 \mathrm{~g}$ of soil [19]. Hydrolytic acidity is an indicator of the degree of saturation of a sorption complex with hydrogen and aluminum ions. It is used to determine the amount of lime added to the soil for deacidification purposes.

Sewage sludge used for soil fertilization was characterized by a large amount of organic matter, $47 \%$ of dry matter, and alkaline reaction ( $\mathrm{pH} 8.2$ ). The contents of heavy metals in sewage sludge made it possible to use the sludge for agricultural purposes (Table 1). The permissible quantities of heavy metals for such use are as follows: cadmium: $20 \mathrm{mg} / \mathrm{kg}$; copper: $1000 \mathrm{mg} / \mathrm{kg}$; nickel: $300 \mathrm{mg} / \mathrm{kg}$; lead: $750 \mathrm{mg} / \mathrm{kg}$; zinc: $2500 \mathrm{mg} / \mathrm{kg}$; mercury: $16 \mathrm{mg} / \mathrm{kg}$; and chromium: $500 \mathrm{mg} / \mathrm{kg}$ of dry matter of sludge [20].

The contents of polycyclic aromatic hydrocarbons in soil and sewage sludge used for fertilization studies are presented in Table 2. Polycyclic aromatic hydrocarbons content does not have a legal limit in Poland with regard to sewage sludge disposal methods. According to current European Union (EU) standards [18], 11 PAHs (marked with an asterisk in Table 2) in sludge intended for fertilization purposes must not exceed $6 \mathrm{mg} \cdot \mathrm{kg}^{-1} \mathrm{~d}$.m. The results presented in Table 2 show that for the sewage sludge used in this study, the recommended standard was slightly exceeded (by $14 \%$ ) and amounted to $6.9 \mathrm{mg} \cdot \mathrm{kg}^{-1} \mathrm{~d} . \mathrm{m}$. The permissible total of 10 polycyclic aromatic hydrocarbons in the fertilized sandy soil was much greater than $1.4 \mathrm{mg} \cdot \mathrm{kg}^{-1}$, according to the recommendations [21].

Analysis of the 10 polycyclic aromatic hydrocarbons (Table 3) in the experimental objects showed that one year after the fertilization with sewage sludge, the soil was not excessively contaminated with these compounds. Despite a significant increase in the content of aromatic hydrocarbons in soils fertilized by sludge compared to control facilities, the soils did not show excessive pollution, which indicates contamination with polycyclic aromatic hydrocarbons. Compared to the standards recommended in Poland for soil quality [21], the contents of 10 polycyclic aromatic hydrocarbons in objects fertilized with sewage sludge (even for the highest doses) did not exceed the permissible content of $1.4 \mathrm{mg} / \mathrm{kg}^{-1} \mathrm{~d}$.m. for this type of soil, which was cultivated at the depth of sampling up to $25 \mathrm{~cm}$. The permissible values for naphthalene, dibenzo(a,h)anthracene, benzo(a)anthracene, benzo(a)pyrene, benzo(b)fluoranthene, and benzo(k)fluoranthene were $0.1 \mathrm{mg} / \mathrm{kg} \mathrm{d} . \mathrm{m}$. of soil for each of them and were not exceeded for any fertiliser combination. Furthermore, $0.2 \mathrm{mg} / \mathrm{kg}$ d.m. of soil is permissible for anthracene, chrysene, benzo(g,h,i)perylene, and indeno(1,2,3-cd)pyrene. Additionally, in the case of these compounds, the recommended standards were not exceeded. It was found that sandy soil doses of sewage sludge used for fertilization $(10,20,30$, and $40 \mathrm{t} / \mathrm{ha})$, which are recommended for the use in agriculture in Poland [20], did not cause contamination of soils with PAHs.

Oleszczuk obtained similar results [8]. This researcher emphasized that sewage sludge doses smaller than $75 \mathrm{t} /$ ha can be used without the risk of soil contamination with PAHs. Furthermore, 
he found that fertilization with doses above $150 \mathrm{t} / \mathrm{ha}$ may already represent a real hazard to the soil environment due to excessive accumulation and migration of aromatic hydrocarbons.

Analysis of the 16 polycyclic aromatic hydrocarbons proposed by the IUNG to determine the degree of soil contamination with PAH showed no contamination of the soils studied with these compounds. The proposed standard for non-contaminated soils is $<200 \mu \mathrm{g} / \mathrm{kg} \mathrm{d}$.m. The PAHs between 200-600 $\mu \mathrm{g} / \mathrm{kg}$ d.m. contained in the recommendations indicated insignificant (trace) contamination. The PAHs in the contaminated soils ranged from 600 to $1000 \mu \mathrm{g} / \mathrm{kg} \mathrm{d}$.m. PAH contamination can be considered serious when the evaluated total of these compounds in soils is greater than $1000 \mu \mathrm{g} / \mathrm{kg}$ d.m. [24].

Wołłejko et al. [25] studied the effect of sewage sludge fertilization at doses of 75 and $150 \mathrm{t} / \mathrm{ha}$ on the content of polycyclic aromatic hydrocarbons in soils. The research failed to demonstrate the effect of sewage sludge application on the 16 PAHs evaluated in the soil during the first year after application. Among the 16 PAHs studied, benzo(a)pyrene was the most dominant in the soil samples. In the present study, the dominant compound was naphthalene.

The results presented in Table 4 concern the analysis of polycyclic aromatic hydrocarbons content in the leachate from soils fertilized with sewage sludge. Leachates obtained from control soils that were not fertilized according to the classification [22] contained 6 PAHs of $0.00004,0.00002$, and 0.000006 $\mathrm{mg} / \mathrm{L}$ in the first, second, and third years of the experiment, respectively. These values are similar to waters in the range of characteristic concentrations (geochemical background).

A high positive correlation coefficient between the decrease in migration of the six analyzed polycyclic aromatic hydrocarbons to soil waters and the duration of the experiment were found based on the results (Table 4). In the second year of the experiment, the calculated degree of correlation between these parameters was 0.96 , whereas in the third year of the experiment, this was 0.96 . The values of 0.9 to 1.0 should be considered a full correlation. The highest migration of PAHs from soil fertilized with sewage sludge to soil leachates was observed in the first year after fertilization.

Fertilization of soil with sewage sludge resulted in a pollution increase in infiltrating waters with aromatic hydrocarbons. In the first year after fertilization, the soil leachates contained 0.00005, 0.00006, 0.00008 , and $0.0001 \mathrm{mg} / \mathrm{L}$ in the six PAHs after fertilization, with the doses of 10, 20, 30, and $40 \mathrm{t} / \mathrm{ha}$, respectively. The highest increase of the six PAHs was caused by fertilization with sewage sludge at a dose of $40 \mathrm{t} / \mathrm{ha}$ in the first year of the experiment. However, despite the contamination increase in infiltrating waters with polycyclic aromatic hydrocarbons, especially when compared to leachates from control soils, these values did not confirm the contamination of these waters. After applying the highest dose of sewage sludge introduced into soils for fertilizing purposes, infiltrating waters could be classified as early as the first year of the experiment as a class 1 underground water (in Poland) and characterized as very high-quality waters, which does not indicate an impact of human activity. In other leachates from experimental objects, the polycyclic aromatic hydrocarbons content was within the range of hydrogeochemical background values. In the second and third year of the experiment, the content of PAHs determined in leachates was close to the values determined in the control soils. However, some authors found that PAHs may quickly migrate into the soil profile shortly after sewage sludge fertilization (especially when used at high drainage doses), posing a hazard to groundwater [26].

In the lysimetric experiment, bioaccumulation of 16 harmful polycyclic aromatic hydrocarbons in the biomass from $D$. glomerata were also analyzed. The results (Table 5) indicated a low accumulation of these compounds in plants during the second and third year after sewage sludge fertilization. Analysis of the bioaccumulation of polycyclic aromatic hydrocarbons in D. glomerata biomass (Table 5) found that the plant studied, despite the presence of these compounds in leachate in the second and third year of the experiment, did not accumulate excessive amounts of these compounds in tissues. The quantities of these compounds in plants were below the detection thresholds of the analytical devices used in the study. The correlation coefficient between the six PAHs in leachates and the compounds of the plant biomass calculated based on the research results was 0.21 . No significant correlation was found between the amount of polycyclic aromatic hydrocarbons in soil leachates and their accumulation 
in plants. This phenomenon may be related to the individual reaction of the plants studied or the impossibility of collecting these compounds and leaching them deep into the soil profile.

Furthermore, analysis of the data presented in Table 5 revealed a high mobility and a large increase in the accumulation of selected polycyclic aromatic hydrocarbons in the biomass from D. glomerata in the first year after fertilization.

A positive correlation was also found between the applied sewage sludge dose and the migration of PAHs from leachates to D. glomerata biomass. The highest bioaccumulation was found after the application of sewage sludge with doses of $40 \mathrm{t} / \mathrm{ha}$ (in the first year of the experiment). The correlation coefficient between these factors was 0.89 , which indicates a high correlation. Doses of 20,30 , and $40 \mathrm{t} / \mathrm{ha}$ of sewage sludge led to a significant increase in the content of benzo(a)pyrene in plants above the values considered safe in food and feed, which is particularly hazardous due to its carcinogenic effect. These doses increased the amount of benzo(a)pyrene in the D. glomerata biomass by $138 \%, 288 \%$, and $505 \%$, respectively, compared to non-fertilized objects. The 16 aromatic hydrocarbons accumulated in biomass, especially in the first year after fertilization with sewage sludge, rose significantly, with a dose increase of $20 \%, 158 \%, 537 \%$, and $776 \%$ after dose applications of $10,20,30$, and $40 \mathrm{t} / \mathrm{ha}$, respectively, compared to control objects. Similarly, Cai et al. [5] planted Raphanus dativus on soils fertilized with sewage and confirmed a high accumulation of PAHs in plants one year after being fertilized with sewage sludge. In the second and third year of the lysimetric experiment, the content of accumulated PAHs, including benzo(a)pyrene, decreased to the level of content in plants from control objects or was at a very low level, i.e., below the detection threshold. Kipopoulou et al. [27] found that even eight to nine years after sewage sludge fertilization, biomass yields may accumulate excessive amounts of PAHs. Moreover, Kipopoulou et al. analyzed the bioconcentration of PAHs in vegetables (maize) fertilized with sewage, finding that migration and accumulation of PAHs in plants depends on the plant species. Additionally, researchers observed that most of the polycyclic aromatic hydrocarbons were accumulated in the tissues of above-ground shoots. The research emphasized the role of soil type in the migration of PAHs to the environment, including plant biomass. The migration of pollutants (e.g., polycyclic aromatic hydrocarbons) in the soil is influenced by the soil type, soil $\mathrm{pH}$, and organic matter. The products of its decomposition affect the properties of the soil sorption complex. If it is extended, the buffering properties of the soil do not allow for a rapid migration of PAHs.

There are no uniform EU regulations regarding the maximum permissible levels of these hydrocarbons in foodstuffs and animal feed. In most countries, the maximum permissible content of benzo(a)pyrene (considered to be one of the most carcinogenic hydrocarbons) in smoked food is $1 \mu \mathrm{g} / \mathrm{kg}$. With benzo(a)pyrene adopted as a marker of occurrence and carcinogenic effects of PAHs in food, the EU introduced standards for benzo(a) pyrene content in certain foodstuffs in 2005 [28]. According to the latest studies [29], the amount of benzo(a)pyrene in cereal-based products used for food purposes must not exceed $1 \mu \mathrm{g}$ per kilogram of product. The $D$. glomerata used in this experiment accumulated benzo(a)pyrene in amounts exceeding the standards for fodder and foods only in the first year after fertilization with sewage sludge, having doses higher than $10 \mathrm{t} / \mathrm{ha}$. The increase in bioaccumulation in the D. glomerata biomass from soils after fertilization with sewage sludge in doses of 20,30 , and $40 \mathrm{t} / \mathrm{ha}$ was $138 \%, 288 \%$, and $505 \%$, respectively, compared to the control plants. In the second and third years after fertilization with sewage sludge, no increased accumulation of this compound was found in plants.

Some authors $[17,30]$ have demonstrated that the addition of biochar to sewage sludge used for soil fertilization reduces the bioavailability of polycyclic aromatic hydrocarbons to plants and soil mobility.

\section{Conclusions}

1. We observed an increase of 10 polycyclic aromatic hydrocarbons in soils after fertilizing doses of sewage sludge. The content of these compounds determined in the experimental objects was within the range characteristic for clean soils. 
2. Excessive accumulation of PAHs (especially benzo(a)pyrene) was observed in plant biomass in the first year of a lysimetric experiment after sewage sludge fertilization at doses greater than $10 \mathrm{t} / \mathrm{ha}$. The increase in bioaccumulation of this compound in plant biomass compared to the control objects was $138 \%, 288 \%$, and $505 \%$ after application of 20,30 , and $40 \mathrm{t} / \mathrm{ha}$, respectively. These values were indicative of significant biomass contamination with $D$. glomerata benzo(a)pyrene.

3. Fertilization with sewage sludge did not cause contamination with PAHs in water leachates from the soils examined for any doses. If this water continues to infiltrate the soil profile, there is no doubt that the quality of groundwater will be deteriorated.

Author Contributions: E.S.-M. conceived and designed the experiments and performed the experiments; E.S.-M., L.S., and U.K. analyzed the data and wrote the paper.

Acknowledgments: The research have been conducted at the Institute of Environmental Engineering, Czestochowa University of Technology (BS-PB-401/301/12).

Conflicts of Interest: The authors declare no conflict of interest.

\section{References}

1. Silva, J.D.; Leal, T.T.; Araujo, A.; Araujo, R.; Gomes, R.; Melo, W.; Singh, R. Effect of different tannery sludge compost amendment rates on growth, biomass accumulation and yield responses of Capsicum plants. Waste Manag. 2010, 30, 1976-1980. [CrossRef] [PubMed]

2. Reinthaler, F.F.; Feierl, G.; Galler, H.; Haas, D.; Leitner, E.; Mascher, F.; Melkes, A.; Posch, J.; Winter, I.; Zarfel, G.; et al. ESBL-producing E. coli in Austrian sewage sludge. Water Res. 2010, 44, 1981-1985. [CrossRef]

3. Aparicio, I.; Santos, J.L.; Alonso, E. Limitation of the concentration of organic pollutants in sewage sludge for agricultural purposes: A case study in South Spain. Waste Manag. 2009, 29, 1747-1753. [CrossRef] [PubMed]

4. Villar, P.; Callejon, M.; Alonso, E.; Jimenez, J.C.; Guiraum, A. Temporal evolution of polycyclic aromatic hydrocarbons (PAHs) in sludge from wastewater treatment plants: Comparison between PAHs and heavy metals. Chemosphere 2006, 64, 535-541. [CrossRef] [PubMed]

5. Cai, Q.; Mo, C.; Wu, Q.; Zeng, Q. Polycyclic aromatic hydrocarbons and phthalic acid esters in the soil-radish (Raphanus sativus) system with sewage sludge and compost application. Biores. Technol. 2008, 99, 1830-1836. [CrossRef] [PubMed]

6. Oleszczuk, P.; Baran, S. Influence of soil fertilization by sewage sludge on the content of polycyclic aromatic hydrocarbons (PAHs) in crops. J. Environ. Sci. Health A 2005, 40, 2085-2103. [CrossRef] [PubMed]

7. Abdel-Shafy, H.I.; Mansour, M.S.M. A review on polycyclic aromatic hydrocarbons: Source, environmental impact, effect on human health and remediation. Egyptian J. Petroleum 2016, 25, 107-123. [CrossRef]

8. Oleszczuk, P. Persistence of polycyclic aromatic hydrocarbons (PAHs) in sewage sludge-amended soil. Chemosphere 2006, 65, 1616-1626. [CrossRef]

9. Oleszczuk, P. Investigation of potentially bioavailable and sequestrated forms of polycyclic aromatic hydrocarbons during sewage sludge composting. Chemosphere 2007, 70, 288-297. [CrossRef]

10. Bernacka, J.; Pawłowska, L. Potentially Toxic Substances in Sludge from Municipal Sewage Treatment Plants; Instytut Ochrony Środowiska: Warszawa, Poland, 2000.

11. Sayara, T.; Borràs, E.; Caminal, G.; Sarrà, M.; Sánchez, A. Bioremediation of PAHs-contaminated soil through composting: Influence of bioaugmentation and biostimulation on contaminant biodegradation. Int. Biodeterior. Biodegrad. 2011, 65, 859-865. [CrossRef]

12. Lu, Y.; Zheng, G.; Zhoua, W.; Wang, J.; Zhou, L. Bioleaching conditioning increased the bioavailability of polycyclic aromatic hydrocarbons to promote their removal during co-composting of industrial and municipal sewage sludges. Sci. Total Environ. 2019, 665, 1073-1082. [CrossRef] [PubMed]

13. Chang, B.V.; Chang, S.W.; Yuan, S.Y. Anaerobic degradation of polycyclic aromatic hydrocarbons in sludge. Adv. Environ. Res. 2003, 7, 623-628. [CrossRef]

14. Włodarczyk-Makuła, M.; Janosz Rajczyk, M.; Wiśniowska, E.; Zarębska, A.; Zgrzebna, A. Examinations of PAHs content in sewage sludge (in Polish). Ochrona Środowiska 2000, 4, 15-19. 
15. Boruszko, D. Research on the influence of anaerobic stabilization of various dairy sewage sludge on biodegradation of polycyclic aromatic hydrocarbons PAHs with the use of effective microorganisms. Environ. Res. 2017, 155, 344-352. [CrossRef]

16. Stefaniuk, M.; Oleszczuk, P. Addition of biochar to sewage sludge decreases freely dissolved PAHs content and toxicity of sewage sludge-amended soil. Environ. Pollut. 2016, 218, 242-251. [CrossRef] [PubMed]

17. Stefaniuk, M.; Tsang, D.C.W.; Ok, Y.S.; Oleszczuk, P. A field study of bioavailable polycyclic aromatic hydrocarbons (PAHs) in sewage sludge and biochar amended soils. J. Hazard. Mater. 2018, 349, 27-34. [CrossRef] [PubMed]

18. European Union Draft Directive on Sewage Sludge (2000). Brussels, 27/04. pp. 1-20. Available online: http://ec.europa.eu/environment/archives/waste/sludge/pdf/sludge_disposal3.pdf. (accessed on 6 April 2019).

19. Ostrowska, A.; Gawliński, S.; Szczubiałka, Z. Methods of analysis and evaluation of soil and plant properties. Catalog of the Institute of Environmental Protection: Warszawa, Poland, 1991. (In Polish)

20. Regulation of the Minister of the Environment of 6 February 2015 on municipal sewage sludge. Available online: http://prawo.sejm.gov.pl/isap.nsf/download.xsp/WDU20150000257/O/D20150257.pdf (accessed on 6 April 2019).

21. Regulation of the Minister of the Environment of 1 September 2016 on the method of conducting the assessment of pollution of the earth surface. Available online: http://prawo.sejm.gov.pl/isap.nsf/download. xsp/WDU20160001395/O/D20161395.pdf (accessed on 6 April 2019). (In Polish)

22. Regulation of the Minister of the Environment of 21 December 2015 on Criteria and methods for assessing the status of bodies of groundwater. Available online: http://prawo.sejm.gov.pl/isap.nsf/download.xsp/ WDU20160000085/O/D20160085.pdf (accessed on 6 April 2019). (In Polish)

23. Kabata-Pendias, A.; Piotrowska, M.; Motowicka-Terelak, T. Fundamentals of Evaluation of Chemical Soil Contamination (Heavy Metals, Sulphur and PAH); Państwowa Inspekcja Ochrony Środowiska IUNG w Puławach: Puławy, Poland, 1995.

24. Oleszczuk, P.; Baran, S. Concentration of polycyclic aromatic hydrocarbons in sewage sludge-amended soil. Commun. Soil Sci. Plant Anal. 2005, 36, 1083-1097. [CrossRef]

25. Wołejko, E.; Wydro, U.; Jabłońska-Trypuć, A.; Butarewicz, A.; Łoboda, T. The effect of sewage sludge fertilization on the concentration of PAHs in urban soils. Environ. Pollut. 2018, 232, 347-357. [CrossRef]

26. Oleszczuk, P.; Baran, S. Leaching of individual PAHs in soil varies with the amounts of sewage sludge applied and total organic carbon content. Pol. J. Environ. Stud. 2005, 14, 491-500.

27. Kipopoulou, A.M.; Manoli, E.; Samara, C. Bioconcentration of polycyclic aromatic hydrocarbons in vegetables grown in an industrial area. Environ. Pollut. 1999, 106, 369-380. [CrossRef]

28. Commission Regulation (EC) No. 208/2005 of 4 February 2005. Available online: https://eur-lex.europa.eu/ LexUriServ/LexUriServ.do?uri=OJ:L:2005:034:0003:0005:EN:PDF (accessed on 6 April 2019).

29. Commission Regulation (EC) No. 1881/2006 of 19 December 2006 Setting Maximum Levels for Certain Contaminants in Foodstuffs. Available online: https:/eur-lex.europa.eu/legal-content/EN/TXT/PDF/?uri= CELEX:02006R1881-20170728\&from=EN (accessed on 6 April 2019).

30. Waqas, M.; Khan, S.; Qing, H.; Reid, B.J.; Chao, C. The effects of sewage sludge and sewage sludge biochar on PAHs and potentially toxic element bioaccumulation in Cucumis sativa L. Chemosphere 2014, 105, 53-61. [CrossRef] [PubMed]

(C) 2019 by the authors. Licensee MDPI, Basel, Switzerland. This article is an open access article distributed under the terms and conditions of the Creative Commons Attribution (CC BY) license (http://creativecommons.org/licenses/by/4.0/). 